\title{
Creative Competence, Artistic Expression and Art Therapy: New Psychoeducational Horizons
}

\author{
Helena Chacón-López ${ }^{1}$, Michal Růžička ${ }^{2}$, Erika González-García ${ }^{1} \&$ M. Jesús Caurcel ${ }^{1}$ \\ ${ }^{1}$ University of Granada (Spain) \\ ${ }^{2}$ Palacký University (Czech Republic) \\ Recepción: 4 de abril de 2016 | Revisión: 6 de abril de 2016 | Aceptado: 11 abril de 2016 \\ Correspondencia: helenachacon@ugr.es \\ Citar: Chacon-Lopez, H., Gonzalez-Garcia, E., \& Růžička , M. (2016). Creative Competence, Artistic Expression and Art Therapy: \\ New Psychoeducational Horizons. ReiDoCrea, 5, 69-77.
}

\begin{abstract}
The development of creative competence, through artistic expression is being forgotten in recent times. Moreover, new practices such as art therapy open the way from the field of psychotherapy to education to help fill these gaps by providing tools and strategies for both teachers and students for the integral development of individuals, promoting creativity and imagination, among others. This article discusses the importance of developing creative competence, through artistic expression and art therapy practices that have found benefits both in lifelong education, and clinical performance, helping to prevent or heal existing conditions, achieving improvement of individual and collective welfare.
\end{abstract}

Keywords: Art Therapy | Creative Competence

La competencia creativa, la expresión artística y la arteterapia: nuevos horizontes psico-educativos

Resumen: El desarrollo de la competencia creativa, a través de la expresión artística está siendo olvidada en los últimos tiempos. Asimismo, nuevas prácticas como la arteterapia se abren camino, desde el ámbito de la psicoterapia al educativo, para ayudar suplir estas carencias, proporcionando herramientas y estrategias tanto al profesorado, como al alumnado, para conseguir el desarrollo integral de las personas, potenciando la creatividad y la imaginación, entre otras. Este artículo expone la importancia del desarrollo de la competencia creativa, a través de la expresión artística y de la arteterapia, prácticas que han constatado beneficios tanto en los procesos educativos a lo largo de la vida, como en la actuación clínica, ayudando a prevenir o curar patologías existentes, consiguiendo una mejora del bienestar individual y colectivo.

Palabras clave: Arteterapia | Competencia Creativa

\section{Introduction and Current Situation}

For years society has been making great strides; more in recent years, in which technologies have accelerated the evolutionary process of societies and, consequently, of human beings. In this sense, research in various scientific and pseudo-scientific fields has played a fundamental role. As well as creativity, we should understand it as the force that fosters the development of interests, motivations and helps to undertake any type of research activity. It is the creative process that makes the world change. Furthermore, creativity and imagination enhance freedom and social and intellectual emancipation (Chacon-López \& González-García, 2015).

Given the social, historical, educational and artistic discourse that has been produced and influenced by the dominant or hegemonic classes, including those of spiritual domination, with their ideological-political traditionalism / conservatism correlates, we see a reformist and revisionist society promoting ideological submission and lack of critical thinking. Since the process of European convergence began, the Bologna plan, quality standards, etc., educational systems have constantly been trying to attempt to adapt, which has been achieved with varying degrees of success, as is analysed. The ultimate goal was to take the step to get an education that cares about the global and comprehensive development of students, and is not centered merely on the transmission of knowledge (Porto, 2008). That global development, in turn, focuses on the productive projection that students will make in society; that is, higher education 
must be productive. The transformation towards education for employment, allowing companies to participate in the design and development of curricula, also establishes education as a commodity. This would not be negative if it were not that these companies (mostly private), had the legitimacy to establish what the individual and collective ideology will be, what is needed to continue to support economic and social systems that hegemonic forces have established (Chacon López \& González-García, 2015). Aspects such as improving the "quality" and "level", improvements turned into fallacies, continue to feed one point: the assessment of efficiency, preparing people for a set or established way of life-or indoctrination- a life armoured by a model of class and status. Thus, it can be established that what is taught and learned is to how to get into the game of supply and demand. As Apple (2002) states: "It is impossible to understand the current educational policy of the United States without placing it in an international context. For example, after the insistence on higher demands, on more stringent tests in education for employment and a much closer relationship between education and the economy in general, we find the fear of losing international competitiveness, as well as jobs and money".

With this movement, there appeared a term that was considered new, but was already inherent in many educational and pedagogical movements- competences or skills. And with that, a competent being; but not promoting the overall integral development of individuals, but for them to be considered competent in three fundamental areas: maths, reading and science (Organisation for Economic Co-operation and Development - OECD, 2012). However, those who considered themselves so important belonged to an organization that has nothing to do with education, but with the economy. But this is for those who allow themseves to mark the training and education guidelines, from primary school through to university. The question is: should it be understood, then, that a person achieves their integral development when they are "competent" in these areas? Where are their social skills, artistic and physical expressions, their emotions? So strong is the conviction and social propaganda that we could think that we are at the gates of Nietzsche's Übermensch. Therefore, the aim of this study is to defend the presence and the importance of artistic expression (in whatever form) and creative competence, because they are associated with motivation, divergent thinking, research and progress; and art therapy, a practice that has proved beneficial both in lifelong education and clinical performance, helping to prevent or cure existing diseases, achieving an improvement of individual and collective well-being; aspects of vital importance in the formation of children, so we reflect on what type of society we live in and what kind of society we want to build.

\section{Competence, Creativity and Creative Competence: Autonomy, Passion and Progress}

The OECD (2005) defines competence as more than knowledge and skills; it involves the ability to meet complex demands, based on psychosocial resources (including skills and attitudes) in a particular context.

Zabala and Arnau (2007) point out that competences are: "effective action in different areas of life by actions that are mobilized at the same time and in an interrelated manner, by attitudinal, procedural and conceptual components". As this definition implies "taking effective actions to situations and problems of various kinds, requires the use of the resources available" (Irigoyen, Jimenez and Acuña, 2011). In the field of higher education, Ruiz (2009) states that the convergence of two events is needed to perform competency-based education. First, by rethinking education in 
facilitating learning, explaining that the process of learning takes place when it is the person who is learning. And secondly, by improving the training of professionals to be able to solve problems efficiently in the real world, without compromising the conceptual, procedural and attitudinal areas. That is, moving from discussion to solving real problems, where the teacher is a guide to solving them.

Thus, according to the OECD (w. d.), skills assessment seeks to identify the existence of certain abilities, aptitudes and skills that enable a person to solve the problems and situations of life. And it divides them into two groups: the basic, linked to school education, such as reading, writing and arithmetic; and general, which includes communicative competence or skills or collaborative creativity.

Creativity, as defined by Guilford (1952) refers to "the aptitudes that are characteristic of creative individuals, such as fluency, flexibility, originality and divergent thinking". For Torrance (1965) it is "a process that turns someone sensitive to the problems, deficiencies, cracks or gaps in knowledge and leads him or her to identify problems, find solutions, to speculate or make assumptions, approve and test these hypotheses, to modify them if necessary in addition to reporting the results". And Gardner asserts (1999) "it is not a kind of fluid that can flow in either direction. The life of the mind is divided into different regions, which I call 'intelligence', like mathematics, language or music. And a certain person can be very original and inventive, imaginative, even iconoclastic, in one of these areas without being particularly creative in any of the others".

The development of creativity is achieved by educating and training it. As Robinson (2011) states: "learn to be creative as you learn to read". This training process can be evaluated day by day, seeing efficiencies in this behaviour, how people face the problems and the quality of the results obtained, thus leading to the construction of creative competence. Therefore, if the creative learning process is seen from the perspective of Psychology and Educational Sciences, related to the general process of learning, it can be realised that the former will involve changes in people who acquire more skills and skills in problem- solving both personally, and professionally.

As for creative competence, there are subjects in the curriculum that cannot be deleted or substituted or forgotten. However, for centuries, humans have left evidence of their passage through their art; it has had, and still has, history throughout it. The most convincing artistic perspective can be choosen individually or collectively: as behaviour, culture, conscious creation, craft, form, creative product, aesthetic experience, selfexpression, historical construct, merchandise, games, visual culture, symbolic system, etc.; because, as Hogarth (1968) noted, "drawing and painting are just a more complicated way of writing".

In teaching and learning, or in the development of creative competence, there are two instrumental areas that are usually present in all school curricula: Artistic and Musical Education. Sometimes the time spent on them is occupied by other subjects considered to be more important, so it is difficult when the time is not available; and that most teachers are not able to define and defend the importance and the reason for their teaching. Therefore, as Alvarez (2007) states: "before teaching, learn, analyse, assess, advise on programmes and artistic learning, we need to know and understand what we are talking about when we talk about the visual arts", or musical arts, body language, etc.

But not only should musical or artistic expression be considered as basic in and for the development of creative competence. Games play a very important role; indeed, it 
appears before artistic expression as Crook (1980) points out, when he says that by starting games the individual has the opportunity to learn new skills related to both manual dexterity and social skills. The development towards representation through drawing, that is, through the game that employs conduct of realization of signs also develops into an important communication skill.

Moreover, Arqué (2005) in an article on art and visual incapacity stated that the profound object of culture is that of approaching a higher understanding, a greater sensation, and highlighted her favorite definition of art: "art as the ability to solve problems".

Despite the multiple definitions of artistic expression and creative competence in all its forms, studies about the benefits for human development, to remove barriers, to communicate with others make it seem curious to find that is an area that continues to fall into oblivion. In a global system based on the reproduction of contents, models or attitudes, we are not interested in and two fundamental processes do not fit: creativity and imagination; enhancers of freedom and social and intellectual emancipation. In the last sentences of the preface to Gramática de la Fantasía, Rodari (1985) states: "I hope these pages can also be useful to those who believe in the need that imagination has a place in education; who have confidence in children's creativity; who know the value of release that a word may have". The use of every word for everyone "seems a good slogan, a beautiful democratic sound. Not that everyone is an artist, but that no one is a slave".

Creativity and imagination are of no interest to the ruling classes, the hegemonic system, because they lead to opinion, decision, and freedom. What this system wants are brains like "a radio receiver able to tell us what the various stations that are tuned say. As the subject, tied to different sources of ideological transmission, it is capable of spreading its various opinions" (Higueras \& Bembibre, 2011). That is, the subject will lose their share of freedom to submit to the dictates of the State (Lacan, 1992).

\section{Art Therapy: Emancipatory Practice}

In all theories of learning in relation to human development, particularly at an early age, there usually appears the world of the conscious and the unconscious. A first attempt to discover mental processes is found in Platon and his daimon.

Freudian theory defines the conscious as a state of knowledge that involves the presence of a subject, an object and an instrument that establishes a connection between them. The subject is the physical entirety of a perceptive human being; the object is anything outside its system of perception. Subsequent investigation found that humans have the capacity for abstraction and, with this, a new hypothesis is also proposed: that consciousness is a mental superstructure or mentally differentiated area; something that has been developed from the relationship between man and his physical and social environment, as a refinement of a basic pre-existing mindset.

Pavlov (1929), meanwhile, contributed, "human thought appears to us, so to speak, to be wrapped in three robes. The first is the most disturbing, but also the closest to the truth - motion. The second or intermediate is the most decorative-consisting of written signs, graphic signs and graphics symbols. Finally, the third is the most magnificent, but also the most superficial--that covers verbal cues, the symbolism of the word, apart from the immediate expression of thought by the previous two". 
Jung (2004) established a classification of the unconscious as personal (Freud and Jung) and collective (Jung). He believed that the unconscious was divided into these two layers; the most superficial surface is the personal unconscious, whose contents are emotional tone complexes; and a deeper layer, that comes not from experience and personal fulfillment, but is innate, which he called the collective unconscious. In this latter we have images stored since ancient times, vestiges of the life lived by countless individuals ("Yoes") in the past and transformed into conscious formulas (myths, fables, etc.). At this time, Jung (2009) introduced the concept of archetype, defining it as centres of influence or force fields within the unconscious, where all the elements immersed in it are subject to a new order, imperceptible, inaccessible to conscious knowledge.

From when the subject begins to draw he does not wait to have paper and pencil, but draws on any surface and with any device, including his finger. It is one of the first techniques of expression, in this case without the need to use words, he is discovering a whole new world; so he has to have complete freedom and time to experience new sensations. Some authors divide the period of human development into phases, agreeing that artistic development ranges from eighteen months to twelve years of chronological age. At first he will draw, create scribbles, lines and dots, because he has no control over the instruments with which he is working. This phase is called "prerepresentative", in which there is still no perfect hand-eye coordination. This period lasts until the child evolves until, at four years, he is able to represent a single human figure or "stick man" or "man tadpole" (a circle, representing the head and two vertical lines, symbolizing the legs).

The relationship between psychoanalytic theory and the art world appears with Freud and his studies of literary and artistic works, as well as his passion as a collector (Toro, 2010). Later, in 1922, Hans Prinzhorn wrote Bildnerei der Geisteskranken. Ein Beitrag zur Psychologie der Gestaltung und Psychopathologie (The art of the mentally ill. A contribution to the psychology and psychopathology of creation), thereby establishing the foundations of art therapy. Adrian Hill published in 1945 Art versus IIIness in which he showed how art therapy gave hospitalized patients a significant increase in emotional well-being, helping to "arrange the mind, heal their diseases and release their mental anguish" (Hill, 1945; 1951). In his work he demonstrated the interest shown in the artistic expressions of the mentally ill, beyond the value that they might have in the diagnostic field.

Artists like Picasso went through periods of self-therapy through their works; in this case, during his Blue Period (1901-1904), which includes notably La Celestina, The old blind guitarist or the Food of the blind; in which he researches and embodies his anguish, presumably for his father's deterioration and loss of vision, along with his own fear of losing his sight; something that would condition his own work (Ravin and Perkins, 2004). Or Munch, who claimed that painting saved him from "disease, insanity and death, which were the angels that surrounded my cradle and followed me throughout my life" (Bischoff, 2013).

Another author, Dissanayake (1974), asserted that art is a social activity and thought that, like play, artistic behavior, even in private, takes the artist out of himself and puts him in relation to the other. Lowenfeld $(1958 ; 1961)$, said that "if one considers drawing as a process that the individual uses to convey meaning and rebuild the environment, the drawing process is much more complex than the simple attempt at a visual representation [...] it is clear that even the subject himself is included in each drawing, as spectator and actor at the same time". And more recently, Arozamena (2013) states 
that "every creature is actually a plus for being and the bonus of being is nothing more than an effect of creation".

It has been shown that art and music are some of the best forms of therapy, whether to help solve problems, or to prevent them; in fact, there are many cases of people who through art therapy and music therapy have partially or completely eliminated difficulties or limitations that made their life more difficult. Virtually all of these cases are of people who have had traumatic experiences in childhood and even in the early days of their contemplation of the world. All these situations are likely to condition the life of an individual. Kováčová and Guillaume (2014) argued that: "Application of arts in different forms and helping the person whose living is the key to the therapeutic process. The goal of the art therapy is to understand and help the client with solving the problem during his life".

Luzzatto (2014) states that "art therapy is a therapeutic method which use images to simplify the communication in therapeutic environment". And Yakhyaev (2015) establishes that "it is possible to describe art therapy with targeted usage of visual and creative materials during interventions, consultations, psychotherapy, and rehabilitation"; and also in an educational way.

In countries like Finland, indisputable leader in education, among others, art therapy, is implemented in schools as a practice to increase the welfare and development of students. In a recent article, Hautala (2011) showed the benefits of art therapy in the schools of this country expressing them at three levels: 1) Students Level, where the best references concerning welfare improvements, interaction skills and their development, in which curriculum and individual and group participation are found; 2) Community Work Level, which increased cooperation between families and schools, promoting multidisciplinary and community work; and 3) Educational Institutional Level, giving a boost to a new healthier and more satisfying school culture and a new way of learning in a different environment.

In Spain, there are projects like Art for All, created and developed by the Patio Herreriano Museum, with the aim of promoting creativity, social integration, improving autonomy and self-esteem of people with different disabilities; this is done through educational activities and creative processes (Coca et al., 2013).

\section{Conclusions and New Horizons}

Art is part of the personality, since through it people communicate with each other, with their surroundings, express their feelings and opinions and integrate their personalities (Yakhyaev, 2015).

Arostegui (2008) states: "Art is a way of understanding reality whose meaning is derived from individual, unique experience interacting with others through the art object, enabling global understanding of reality in complementarities with the prevailing view".

At this point, there should be a thorough analysis of the practices and values that are held in different contexts; although it is true that society is, as Dietzgen said in 1902, before the most uncertain of uncertain roads (literally der holzweg der holzwege). And power is located in a no-man's land where the forces of capital, finance, drug trafficking, organized crime, etc. reign that have undermined the collective institutions of actions (Bauman, 2013). 
The issue of art education and art therapy are emancipatory practices, at the same time as performing the function of assisting in the integral development of the person. They promote freedom of expression (the way you want), personal and interpersonal relationships, or social skills. Similarly, it has been found, over the years, that they represent a form of valuable therapy, both in the therapeutic process, and prevention of possible pathologies. From a pedagogical point of view, art therapy is seen as a process of educational treatment, through various forms, materials or strategies. But not only for individual-level interventions, but also as a group method, as they enhance the personal and collective well-being and the educational process, understood as lifelong, in order to prevent possible problems, and promote self-knowledge and personal and group growth (Chacon-Lopez \& González-García, 2014; Yakhyaev, 2015).

Hesiod said that education helps people to learn to be what they are capable of being. And following this opinion, teaching should never be repressive. We use art every day; we tell the story of humanity and history tells us about ourselves through it. Therefore, if we work from an artistic, creative, free, expressive, focus rather than continue to educate on abstract concepts and separate from reality, it could lead to a change in the conception of teaching and learning.

It is true that the implementation of other models, such as art therapy, needs resources; but there are increasingly numerous specialists in this field, the teachers involved in this practice; in view of the results they provide and the benefit which it gives in the process of teaching and learning on the one hand, and the prevention and treatment of social, emotional and personal disorders, on the other. This is the path that countries like Finland have chosen, an example to many for a worthwhile education.

To conclude: "the idea of the work is complex [...] It is in this sense, the least that can be said, and all for not calling it by its real name, a real Idea. That there is a inseparable thought and an experience of its words and that are the organization of thinking that is itself, that is, or rather at the same time and in the same movement, the demonstration of that "way of organizing around the void" that Art is; Saying this, all this, we might think, would be justice. But we know that justice is beyond all right" (Arozamena, 2011).

References

Álvarez, M.D. (2007). La traición de las imágenes: ¿para qué la educación artística? Lección inaugural. Facultad de Ciencias de la Educación. Universidad de Granada.

Apple, M.W. (2002). Educar como Dios manda. Mercados, niveles, religión y desigualdades. Barcelona: Paidós.

Aróstegui, J.L. (2008). La formación del profesorado en Educación Musical ante la Convergencia Europea en Enseñanzas Universitarias. Revista de Educación, 341, 829-844.

Arozamena, A. (2011). Reseña tachadura de un modo de organización alrededor del vacío, Brumaria Works \#3 Expanded Violences. Impossibilia, 1, 150-159.

Arozamena, A. (2013). Inusitar e inquietar la maravilla. A propósito del imperativo de eternidad, los procedimientos de verdad y los horizontes de indeterminación. Comunicación presentada en el $50^{\circ}$ Congreso de Filosofía Joven, Granada, Junio de 2013 [Texto cedido por el autor].

Arqué, M.L. (2005). Arte-Ceguera. Integración, 45, 17-24.

Bauman, Z. (2013). La cultura en el mundo de la modernidad líquida. Buenos Aires: Fondo de Cultura Económica. 
Chacón-López, H., \& González-García, E. (2015). La expresión artística y la arteterapia como herramientas emancipadoras. El Genio Maligno. Revista de Humanidades y Ciencias Sociales, 16, 79-95.

Coca, P., Olmos, A., García-Ceballos, S., Delgado, N., García-Vegas, S., Santiago, E., \& Laguens, A.I. (2013). Arte para todos. Proyecto de investigación y creación con personas con discapacidades diversas. Arteterapia: Papeles de arteterapia y educación artística para la inclusión social, 8, 155-168.

Crook, J. (1980). The evolution of human consciousness. Oxford: Oxford University Press.

Dietzgen, J. (1902). L'essence du travail intellectuel. París: Champ Libre.

Dissanayake, E. (1974). A hypothesis of the evolution of art from play. Leonardo, 7(3), 211-217.

Education and Culture DG, Lifelong Learning Programme. (2007). Tuning Educational Structures Europe. Recuperado de http://www.unideusto.org/tuningeu/

Hautala, P.M. (2011). Art therapy in Finnish schools: education and research. Arteterapia: Papeles de arteterapia y educación artística para la inclusión social, 6, 71-86.

Higueras, L. and Bembibre, J. (2010). El caso de Rousseau o la violencia de la educación de clase. El genio maligno. Revista de Humanidades y Ciencias Sociales, 9, 29-39.

Hill, A. (1945). Art versus Illness. Londres: George Allen \& Unwin.

Hill, A. (1951). Painting Out Illness. Londres: Williams \& Norgate.

Hogarth, W. (1968). Hogarth. Paris: Hachette.

Irigoyen, J. J., Jiménez, M. Y., \& Acuña, K. F. (2011). Competencias y Educación Superior. Revista Mexicana de Investigación Educativa, 16(48), 243-266.

Jung, C.G. (2009). Arquetipos e inconsciente colectivo. Barcelona: Paidós.

Jung, C.G. (2004). La dinámica del inconsciente, Volumen 8. Obras completas. Madrid: Trotta.

Ováčová, B. \& Guillaume, M. (2010). Art vo vzdelávaní. Študijný materiál pre študentov (ne)pedagogických študijných programov. Trnavská univerzita $\vee$ Trnave, Pedagogická fakulta.

Lacan, J. (1992). El Seminario. Libro XVII: El reverso del psicoanálisis. Texto establecido por Jacques- Alain Miller. Barcelona: Paidós.

Lowenfeld, V. (1958). El niño y su arte. Buenos Aires: Kapelusz.

Lowenfeld, V. (1961). Desarrollo de la capacidad creadora. Buenos Aires: Kapelusz.

Luzzatto, P. (2014). The Search for the Art Therapy Method: One or Many? Art Therapy OnLine, 5(1).

Pavlov, I. P. (1929). Los reflejos condicionados. Lecciones sobre la función de los grandes hemisferios. Madrid: Morata.

Organisation for Economic Co-operation and Development (OECD). (2005). The definition and selection of key competencies. Executive summary, Recovered from www.oecd.org/edu/statistics/deseco

Organisation for Economic Co-operation and Development (OECD). (2012). Programme for International Student Assessment (PISA), Recovered from http://www.oecd.org/pisa/home/

Porto, M. (2008). Evaluación para la competencia creativa en la educación universitaria. Cuadernos FHyCS-UNJu, 35, 77-90.

Prinzhorn, H. (1922). El arte de los enfermos mentales. Una contribución a la Psicología y a la Psicopatología de la creación. Berlin: Springer.

Ravin, J. G., \& Perkins, J. (2004). Representations of Blindness in Picasso's Blue Period. Archives of Ophthalmology, 122(4), 636-639. 
Robinson, K. (2011). El elemento. Descubrir tu pasión lo cambia todo. Madrid: DeBolsillo.

Rodari, G. (1985). Gramática de la Fantasía. Introducción al arte de inventar historias. Barcelona: Hogar del Libro.

Ruiz, G. (2009). El enfoque de la formación profesional en torno a la generación de competencias: ¿ejercicio impostergable o "lo que sucedió a un rey con los burladores que hicieron el paño?. Estudios Pedagógicos, 35(1), 287-299.

Toro, D. (2010). Arte y psicoanálisis. Virtualia, Revista digital de la Escuela de la Orientación Lacaniana, $20,2-7$.

Yakhyaev, Z. (2015). Artherapy in system of expressive therapies. Journal of Exceptional People, 7(2), 7-17.

Zabala, A. y Arnau, L. (2007). La enseñanza de las competencias. Aula de Innovación Educativa, 161, 40-46. 